\title{
Urban Crisis Writing in Paul Auster's Novels
}

\author{
Long Shi \\ College of Foreign Languages \\ Pingdingshan University \\ Pingdingshan, China
}

\begin{abstract}
In Paul Auster's Novels, the writer pays special attention to the urban crisis writing: spiritual and ethical crisis, the racial prejudice and terrorist violence. In various crises in the city, compared to the mild spiritual and ethical crisis, the racial prejudice is more radical, even violent, while the crisis reaches the peak in terrorism. Auster's consciousness of the urban crisis is unprecedented, and the urban crisis writing occupies a prominent position in the literary imagination, which becomes the central theme and the starting point of his thinking. Auster's writing on different crises expresses his critical thinking on the city of the past and present as well as his concern on the city in the future.
\end{abstract}

Keywords-Paul Auster; novels; urban crisis writing

\section{INTRODUCTION}

Although Edward Glaeser, in Triumph of The City, enthusiastically praises the city as the great miracle and exalts the prosperity of the city, he intentionally neglects the challenges and crises the city faces. Developing up to present, city has become a "soft" opened Pandora box which is full of the unprecedented crises. Some crises even have endangered the existence of human beings. In his novels, Auster makes a close description of various crises in city. For Auster, the intention of writing the urban crises is not just to expose them, he urges us to attach great importance to the crises. This paper firstly examines the spiritual and ethical crisis of city life - the consumption controlled by technology and media, the deconstructed traditional ethics and the entertainment of gambling. Then the racial prejudice in city in novels will be analyzed, which is centered on the prejudice against the black and Jews. Last but not least, terrorist violence will be explored, especially Auster's attitude and his own understanding of war on terror.

\section{The CITY AND MENTAL LIFE: SPIRITUAL AND ETHICAL CRISIS}

\section{A. Consumption: Systematic Act of the Manipulation of Signs}

Jean Baudrillard argues that the capitalist society has entered consumption-oriented society since 1960s, "There is all around us today a kind of fantastic conspicuousness of consumption and abundance, constituted by the multiplication of objects, services and material goods, and this represents something of a fundamental mutation in the

This paper is a part of project: PXY-BSQD-2018019, and sponsored by Pingdingshan University. ecology of the human species. Strictly speaking, the humans of the age of affluence are surrounded not so much by other human beings, as they were in all previous ages, but by objects"[1]. In the traditional sense, the object of the consumption is goods, or the direct object is the value of the use of goods, which is to meet people's physical and physiological needs. In modern time, the meaning of consumption changes a lot. In consumption, the objects become signs, "In order to become object of consumption, the object must become sign; ... it becomes "personalized," and enters in the series, etc., it is never consumed in its materiality, but in its difference" (ibid). In city, the signs, the basic elements of consumer society, are full of life. On the surface, people consume objects; actually, they consume the image and signs disguised as an object it becomes.

In Timbuktu, through a dog's consciousness, Auster expresses his concern of people's dilemma in a consumer society. Willy's Americanization process starts with playing "stickball in the streets, read Mad Magazine ... and listened to Buddy Holly and the Big Bopper" (TB 15). Willy constructs his identity through cultural consumptions as Hugh Mackay interpretes Baudrillard's statement: "We become what we consume" [2]. Willy is manipulated to form an identity within the framework of fixed Americanization that is presented to him through the producers, mainstream culture. Among the goods, he consumed since a little boy, hair trainer is just the tip of the iceberg, castor oil, pot cheese, lumpy porridge, Blackjack gum. "We all grew up with that junk", there are some other useless bits of knowledge. Under the influence of consumer culture, people admire the celebrities, hoping to gain something important to him. However, that is not real, it is simulations, as Baudrillard states, "to simulate is to feign to have what one does not have" [3]. The emergence and prosperity of mass media accelerates the symbolization of consumption and change the way of consumption. Media is not a traditional propaganda tool, it can not only endow the products a variety of meaning, but also induce the desire of consumer and produce endless consumer demand through the spreading of concept and significance. The simulation world is constructed through the media, like TV and film. What the media present us is the "true lies" or "false real", what people see is the processed simulation, like what the prisoners see in the cave. Advertisements set up the real stage for simulacra, as advertisements for "Pall Malls and shopping malls, Milton Berle and Burl Ives, Ivory soap and Aunt Jemima pancake", which is well illustrated by Baudrillard's remarks 
"advertising is perhaps the most remarkable mass medium of our age" [4]. Facing and living in the simulacra since very young, Willy realizes the unreality of life. In his identity construction, the food and soap labels and advertisements plays an important role, which marches through his brain like "long-lost brethren".

For Willy, simulacrum resulted from consumption is omnipresent and omnipotent, therefore, Willy managed to make adjustment within the simulation. In his college days, he tried to escape from everything through ingesting in drugs, and then he returned to his mother's apartment. One day, it was two-thirty in the morning; a vision on TV enabled his transmission into his own simulacrum. In his vision where he saw Santa Clause talking to him through the TV set. The shopping on Christmas Eve is a carnival and feast of the consumption culture in city. Willy knew Santa was fake for Christmas on the street, let alone on TV. But out of curiosity or he wanted to make sure he wasn't having another breakdown, Willy turned the television back on and he found Santa Clause, the simulated hero figure he watches on the screen, lectured for frightened and bewildered Willy, Willy wept his eyes out as he begged for mercy and promised to mend his ways. Finally, he creates the meaning and aim in his life. Willy's vision becomes "more real than the real". Having decided to turn himself into a saint, Willy quickly changes his last name to Willy Christmas and has himself tattooed with a picture of Santa Clause early morning next day. Therefore, Willy creates his own simulacra within the simulacrum of TV. While Baudrillard puts forward his theory of simulacra in consumer society, the novelist Auster takes his theory further in his novel. In Timbuktu, readers enter into a simulacrum created by Auster, "where, dogs tell stories and think, where Santa Clause could speak to people from inside the TV set, where the dead people move to a place called Timbuktu in which dogs can also speak just like human beings" [5].

\section{B. The Daily Communication: Deconstructed Traditional Ethics}

From the beginning of his literary career, Auster instilled a strong sense of isolation between man and woman in his works. In The Book of Illusions, Invisible, The Locked Room and The Oracle Night, the characters have a vague family ethics, affairs and chaos of sex, which can be seen as a representation of insatiability and degeneration in urban development. In the postmodern metropolis, people enjoy more freedom in sex relations based on contingency and capriciousness. Obviously, the sex writing: sex performance, incest, and adultery in Auster's novels are not served to discuss the ideal marriage mode, but to reveal the crisis of the deconstructed traditional ethics.

The Book of Illusions is set in "the Roaring Twenties" in America. Auster depicted vividly Hector's sex performance with a prostitute, Sylvia Meers, as a representative of crazy life of sexual liberation of the generation. In six months, they appeared together some forty-seven times. People from all walks of society like to see the sex performance, "Bankers and lawyers, businessmen and politicians, athletes, stockbrokers, and representatives of the idle rich".
Regardless of the size of the city, their performances are very popular. "Most of the work took place in and around Chicago, but some bookings came in from as far away as Minneapolis, Detroit, and Cleveland." The venues varied "ranged from nightclubs to hotel suites, from warehouses and brothels to office buildings and private homes." The audience sometimes "consisted of about a hundred spectators" and sometimes "just one (repeated on ten separate occasions for the same man)." They performed both on larger gatherings (bachelor parties, birthday celebrations) and the smaller groups. The contents of the acts varied according to the wishes of the clients, "Sometimes Hector and Sylvia put on little plays...based on the most conventional erotic daydreams".

The incest, usually taken as an aberration, a crime against God, nature, humanity, has been considered as one of the most widespread cultural taboos. In Invisible, Walker states his incest story with his sister in second person narrative in a book written for his college friend, Jim, now a famous writer. Walker and his sister were in New York, they are no longer the floundering, ignorant puppies they were on the night of the grand experiment, and what they are doing now is "a monumental transgression, a dark and iniquitous thing according to the laws of man and God". In Invisible, incest has not been an abiding theme anymore, especially in city life. Auster turns his attention to the cultural meaning of memory and trauma. Walker and his sister Gwyn have trauma caused by their family life and the death of their brother. Auster brings to the forefront the relationship between the protagonist's traumatic experience and literature. The literary study of incest in Invisible can sharpen our awareness of trauma not only as a personal, but also as social and cultural experience. Oracle Night is set in Brooklyn, New York. As Auster argues in an interview, "Oracle Night is also a dark book" [6]. Orr wrote the relation, incest between Trause and Grace: first in Portugal, then in New York before Orr and Grace get married, and during the period Orr was in hospital. Oracle Night is in many ways the story of a family's ethical crisis in New York, which is endangered not only by financial problems but also by Orr's encounter with a prostitute and by his wife's incest with her father's friend Trause, resting in her strange behavior since learning about her pregnancy. Same as the marriage crisis in Oracle Night, Locked Room, one of the New York Trilogy is also involved people's ethical crisis in city. On the one hand, the narrator thinks that Fanshawe's mother set him up, on the other hand, he states that a number of ancient feelings towards Fanshawe's mother finally catches him up. Drunkenness is never more than a symptom, not an absolute cause. There is never a harmonious mother-son relation, more importantly, there is the question of motive. Fucking the narrator would be like possessing Fanshawe-like possessing her own son-and in the darkness of this sin, she would have him again - but only in order to destroy him. And the narrator enter into a state of madness,

The alienation of human nature in city is presented by both Fanshawe's mother and the narrator. So far, it is difficult to say who is the person making the trap and who the trapped in the incest. Maybe both of them are trapped, 
but they don't know. With the sexual activity, the narrator succeeds in the duty her son has failed to perform: forming the good relation among the family. With the sexual activity, Fanshawe's mother succeeds in the function her son has failed to perform: becoming the narrator's target to attack. After reading Locked Room, readers cannot find the narrator's name, all the story is told by the first narrative. This is the first time Auster writes novel in this way, the first person narrative generalize the narrator's experience, which further reflects Auster's realization of the universality of ethical crisis in city. Through the narrator, Auster explores the special problems people face in the city in telling their own stories based on alienation power.

\section{Gambling: The City Discipline of Late Capitalism}

Actually, gambling is the key to the house of The Music of Chance, in which Paul Auster, taking the novel as his playground, cryptically presents the crisis caused by discipline of capital ideology in postmodern city.

In the history of humankind, gambling exists for a long time. However, only with the development of capitalism did gambling become an industry. Gambling has been prohibited for the past hundreds of years in capitalist society in many countries until the sixties with the coming of a process of legalization, and then developed into an industry. For instance, in America, the prohibition of gambling in the past, to a large extent, is influenced by the protestant ethic which holds that "labour came to be considered in itself the end of life, ordained as such by God. St. Paul's "He who will not work shall not eat" holds unconditionally for everyone. Unwillingness to work is symptomatic of the lack of grace."[7], "Even the wealthy shall not eat without working, for even though they do not need to labour to support their own needs, ... he should labour." (ibid) In sixties and seventies, gambling takes a new guise in the economic exchange of capitalism. Gambling is now legal in forty eight states in America. Lotteries become terribly popular, particularly among lower-income citizens in the city who view lotteries as a quick chance for radically improving living.

In The Music of Chance, when the poker game ends, Nashe and Pozzi lost all their money, then Nashe and Pozzi must labour to build a wall with ten thousand stones requested by the millionaires as a way to pay gambling debt. When the two millionaires threaten to call the police, they have to accept it, because Nashe understands that the authorities will cooperate with the power and wealth. Althusser argues that "the Repressive State Apparatus functions 'by violence', whereas the Ideological State Apparatuses function "by ideology" [8]. However, the two State Apparatuses work in collaboration with each other to represent the benefits of the ruling class - the capitalist. Thus, gambling legalization functions as ideological state apparatuses to control the society and only a few players and all the investor obtain the profits while most people gain nothing, for instance, Nashe's and Pozzi's father get rich by speculations, the two millionaires win all their money and car while Nashe and Pozzi lose all, even their freedom. For people who are in postmodern society, or late capitalism, are directed to only blame their lack of luck or chance, or fate as the principle governing human life, rather than the social system itself. All the characters come into money by luck and lose it through misfortune. The ruling class, the capitalist, holds state power and has at its disposal the Ideological State Apparatus as main discipline to maintain the social order. In the world of novel, money is never earned. It is always won, acquired either by accident or by manipulation or defraud. In the novel, the two eccentric and ruthless millionaires, Flower and Stone play poker game only for entertainment, while Nashe and Pozzi for freedom. Flower and Stone's behaviors are against the protestant ethic. And the protestant ethic acts powerfully against the "spontaneous enjoyment of possessions"; it "restricted consumption, especially of luxuries". After the loss of all his money, Nashe, as a prisoner in Foucault's panopticon, has become a tamed subject by the ideology of the ruling capitalist class, he even never to question his living condition no matter before or after the poker game. He remains rational to build the wall to pay debt under the indirect surveillance by Flower and Stone, persuading Pozzi to fulfill the contract. Interestingly, on the surface, Nashe and Pozzi are monitored overtly by the figure of the servant, Murks, but ultimately by almost invisible and intangible forces of capital itself represented by two millionaires. Pozzi, on the other hand, firstly takes violent way to complain, Pozzi also does not realize the power of discipline behind capitalist ideology, on the contrary, he becomes superstitious, he thinks that Nashe was the cause of his bad play by breaking "the rhythm", because Nashe break the balance of the universe by changing "the City of the World" and steal one of its figurines, Pozzi attributes all his loss and stuckness to lack of luck, his escapement ends with severely physical punishment because of two millionaires' prolonged labor, becoming the victim of the discipline of ideology.

In a word, The Music of Chance offers an exploration of the manner in which ideology functions as main way of discipline. As Tim Woods accurately observes, the disciplinary techniques used during the erection of the wall, include timetables, constant imposition and regulation of activity, surveillance measures to monitor performance, and guards [9]. The title, The Music of Chance, implies an paradox state of affairs, music is suggested with harmony and symmetry, order, chance is associated with the opposite ideas. This paradoxical "ordered disorderedness" is the metaphor of the crisis in the city, in addition with the sudden ending of the novel with its unspecified suggestion of a car crash. Capitalism as a giant casino, people are all gamblers in a sense, and the gambler's goal is not to be favored by Lady Luck but to become her "Knight".

\section{THE CITY SCAR: THE RACIAL PREJUdICE}

Ethnic and racial diversity has become one of the major characters in urban development. However, in the city crisis, compared to consumption, sex and gambling, the racial prejudice has become more radical. In Auster's novels, the whites presently occupy a majority privileged position in the mainstream culture, although there is a great difference 
between blacks and Jews, both the blacks and Jews become the target of racial prejudice.

\section{A. The Black and the White}

The protagonists of Ghosts are deliberately cryptic; their "names" are merely color terms. The relationship between the representative reading of the postmodern perspective and the racial conflicts and prejudice in the city mainly in Ghosts will be examined. From a postmodern perspective, to understand "ethnic" or "race" would commonly be quick to dissolve not only the binary opposition of "white" and "black", but also the ideological discourses that put up their construction. Ghosts makes this point more complex, while postmodernism in general, and Auster in particular, work diligently to deconstruct self/other binaries in a theoretical sense. It is not an exaggeration to say that Ghosts is a novel dedicated primarily to the description of racial domination in the city. What is clear, however, is that Ghosts is not willing to see race or ethnic problem can be ignored in the city, whether it is in the past, the present, or the future. In Ghosts, Blue, the detective, is metaphorically imprisoned in a small room to spy on another man, Black, and waiting and wishing for Black to do something. Blue does not give special attention to the bronze statue, more exactly, the race, or, "color," despite his name, but Auster does. The statue builds Beecher as the white hero of the abolitionist movement. Beecher's sculpture depicting him freeing the slaves reminds Blue of how imprisonment, domination, and even emancipation in this country, as later, Black tells Blue that before paying Walt Whitman a visit Thoreau went to hear Henry Ward Beecher's sermon in Plymouth Church, a place which was also visited by Abraham Lincoln and Charles Dickens.What's more, the racial conflicts in the city are enhanced by the next episode. Little by little, Blue becomes more audacious in his strayings from Black. As he takes his seat at the ball park, he is struck by the sharp clarity of the colors around him: the green grass, the brown dirt, the white ball, the blue sky above. Each thing is distinct from every other thing, wholly separate and defined...Watching the game, he finds it difficult to take his eyes off Robinson, lured constantly by the blackness of the man's face, and he thinks it must take courage to do what he is doing, to be alone like that in front of so many strangers, with half of them no doubt wishing him to be dead.

Finally, when Blue disarms Black and attacks him at Black's apartment, rendering him unconscious, possibly dead. That is, blacks should take violence to gain their freedom, and "self-respect", rather than expect to be freed by whites, freedom is a result of black's struggle rather than a gift by whites. This point is ironically expressed in Ghosts' statue of Beecher and relief of Lincoln who is portrayed as "giving" the slaves their freedom. Blue's final violence too might be seen as a struggle for his freedom against his master. Not only does Blue kill his "master," White, but he also simultaneously kills the images of both "White" and "Black" and still the binary opposition of the master/slave dichotomy. Blue has to understand that White and Black are the same person. His secretive, elusive employer White does not exist after all; he is quite literally absent, because he is the absence of color: he is Black. Blue's identity begins to decay, together with Black's, White's and Blue's, three subjectivities collapses. Just as the dissolution between Black and White as characters (and as races), the blurring of color connotation is deconstructed, and the direct reference Blue initially attributes to words, colors, and races is subverted. If, according to postmodern/poststructuralist logic, the divisions between black and white are unsound, then the basis for oppression and prejudice based on such divisions must also be untenable.

\section{B. From Prejudice to Persecution: Anti-semitism in City}

A much similar parallel to the racial prejudice of the black may be found in maltreatment, even persecution, of Jews in the city. Like that of the blacks, Jews suffering experience extended for many centuries over many countries. However, there is a great difference of hostility between the two races. Although, there have been outbreaks of racial violence in the city, in history, Jews in the city were isolated into certain small quarters, usually named as "ghetto". On the other hand, for black haters, their hatred may be cruel and passionate; the hatred for the Jew haters, their purpose is to eliminate the object in camps as in Hitler's war.

In Man in the Dark, Paul Auster explores the racial violence against Jews. The protagonist tells two true stories within story of racial violence against Jews in cities in the past. One story concerns about the human evil and the other is about the human goodness. The first is told by Jean-Luc about an execution. The execution scene, obviously, brings us to Michel Foucault's Discipline and Punish in which Foucault depicts in detail the dismemberment of Damiens on March, 2, 1757. After almost two hundred years, in 1940s, Nazi repeated brutal act. In the years 1939 to 1945 , about five to six million Jews, including one million of them children, sent into camps, and put to death, simply because they were Jews. Another is a story within a story as well. When the Nazis entered into power in 1933, the narrator's grandmother was seventeen or eighteen. A captain in the SS had fallen in love with the girl, he was willing to furnish them with exit visas that would allow them to escape to another country on the condition that their daughter would go to the park, sit down on her favorite bench and stay there for two hours. He needs to see his darling girl one last time before he lost her forever. In the context of antisemitism, Auster explores the power of love which not only saves the whole family, but save the hope for human kind. AntiSemitism is racist discrimination against Jews for the simple reason that they are Jews. In Auster's In the Country of Last things, Auster imagines the antisemitism in the city in future. The narrator is trapped in a country of last things, and a few of the Jews escaped into the library. In the novel, the Jews cannot avoid the destiny of destroy in the future, the special hatred of the Jews obtains its peculiar power from the historical relationship between Judaism and Christianity. The sentence Auster writes reflects the real feeling of Jews, when Anna meets rabbi for the last time, "Every Jew, he said, believe that he belongs to the last generation of Jews. We are always at the end, always standing on the brink of the last moment, and why should we expect things to be any 
different now?" (CLT 130) In the future, in cities, the racist thoughts still exists and also there is a political situation which Jews can be served as the scapegoat. From this aspect, the antisemitism has been embedded in western culture over many centuries, if human beings do not make a reflection, it will erupt at some moments, for instance, hard economic crisis, etc. Rather than reducing as time passed, antisemitism increased during the end of the nineteenth and the first half of the twentieth century. In cities, particularly, the level of antisemitism has become epidemic trend. The description about Jews and antisemitism in the city can be found throughout Auster's writings, from early autobiography until the very end of his novels. As an American Jew and a writers of humanism and appalled by what had happened, Paul Auster examines the the history of antisemitism, and explores the possibilities in the future in his novels

\section{The New City WAR: TerRorist ViOlenCE}

"Terror" is a six-letter word. So is "murder". Terror and murder are among the most irritating words in our dictionary; they are also among the most disturbing features of the human condition in the city. So far, terrorism has become a major threat to the security and interests in the city. Terrorism is the most violent city crisis, not only because it brings damage, but also frightens people in the city, even possibly makes the city extinct with chemical, biological, or nuclear weapons.

\section{A. The Road Less Travelled: Self-examination}

In trying to find the answer to the question "Why do they hate us?" Americans looked at both abroad and in domestic. They sought to learn more about the Arab and Muslim societies from which the 9/11 hijackers and many other members of the al Qaeda terror network came. Some wondered whether the religion of Islam is inherently violent, given that many of the Muslim terrorists and their spiritual leaders profess to act in accordance with religious beliefs. Others wondered whether the answer to 9/11 lay in the grievances of the Muslim and Arab world. Were these terrorists motivated by their dislike for the West because of its history of colonizing the Arab Middle East? Others argued that American policies were to blame, including U.S. possession of military bases in the heart of the Arab world, its attempts to ensure access to cheap oil, and its strong support of Israel and authoritarian Arab regimes in the Middle East. Some commentators looked for economic explanations, arguing that terrorism occurs when societies live, or are forced to live, in dire economic conditions, plagued by high unemployment and low economic growth.

In Leviathan Auster self-examines American culture and criticizes politics. Sachs' critical thinking towards American culture and politics is well expressed in novel The New Colossus he ever published. In the novel, the dominant emotion is anger, a full-blown, lacerating anger that surged up on nearly every page, like Paul Auster, Sachs states questions related to historical facts and fictional characters and writers, however, Sachs's novel almost became outdated. The image that dominates Leviathan by Auster is that of the Statue of Liberty, a conceit which works on multifarious levels. Through the Statue of Liberty, Sachs gets new understanding of American culture and politics for two times. His first visit to the Statue of Liberty when he was young is depicted early in the narrative, which is a good example of how Sachs linked personal experience with American culture and politics. Sachs's second encounter with the Statue of Liberty is equally important, as it works as a turning point forever. It is how Sachs justifies his action to blow up replicas of the Statue of Liberty. Benjamin Sachs realized that American culture and freedom, symbolized by the Statue of Liberty, has become only a fusty and hollow myth, nothing more, and a derision of real freedom defined by its responsibilities to sustaining the values of democracy. Consequently, he sets out to blow up the replicas of the Statue of Liberty that he finds in towns scattered across America, to awaken the dormant political unconscious of the American people. Sachs does not deconstruct the American myths but revivify them. His understanding and selfexamination confronted him with the terrible indifference of the American public to the ideals of democracy, and he resorts to restricted violence, or terrorism, to regain the sense of freedom and democracy.

The epigraph of the novel (Leviathan by Auster) comes from Emerson: "every actual state is corrupt", he writes in 'Politics', and, therefore, "good men must not obey the laws too well" [10]. A similar idea is expressed in "Resistance to Civil Government" and "On Civil Disobedience", which is contributing in shaping Sachs's beliefs and attitudes, where Thoreau put forward a model of passive resistance against unjust governments. Echoing Emerson, he writes: "under a government which imprisons any unjustly, the true place for a just man is also in prison" [11]. The epigraph implies that the writer shares Sachs's idea that America does not live up to the standards preached in international ideals, as symbolized by the Statue of Liberty. However, through Aaron's narrative, we also get the understanding that such corruption and hypocrisy is inevitable and change will only be possible through taking resistance from within the structures of society so as to challenge its practices.

Originally, "leviathan" the word means "twisted", "whirlpool" in Hebrew, while in Christianity "leviathan" is an equivalent of envy in Seven Sins, in Old Testament,

"leviathan" refers to a kind of sea monster in Job, Psalms. In Leviathan in 1651 by Thomas Hobbes, the word is used to refer to a Commonwealth, or State, Auster borrows Hobbes's main conceit, the image of Leviathan as an artificial man, a construct which has different parts corresponding to nature but which is "of greater stature and strength", to some extent, Auster uses it not so much for implications of American culture and politics as for a metaphor for the act of writing, and what that writing reflects of people's lives.

\section{B. Political Critique of War on Terror}

Man in the Dark is a post-9/11 work, whose factual and fictional plot centers on the terrorist attack on the World Trade Center and George W. Bush's controversial leadership. Yet, in the text, Auster returns to the key theme that has preoccupied him since the attack. When Man in the Dark's symbolic and latent return to the theme is examined, the 
novel's political critique can be more richly understood within the context of the topoi of the current issues of contemporary American politics and the reexamination of American culture through writing.

Man in the Dark consists of double plot lines, constructed as a story within a story, the frame story of Man in the Dark is located in a realistic familiar political setting: Bush is as the American president in his second office term; the 9/11 attack occurred in 2001; and America is involved in a war in Iraq - a war that throws its terrible shadow on the lives of Auster's main protagonists. What's more, the embedded story is a fictional narrative coined by the frame story's character, Brill, George Bush's government partly breaks down into opposite parts as some of the states refused to acknowledge the president's reign caused by the dispute over the outcome of the 2000 presidential election, taking a break from the Federation. Brill, as the protagonist of the realist frame story, who invent the embedded story in Man in the Dark, is literally alone in the dark, it is a national dilemma and collective straits for Brill-or for Paul Auster in 2008, which becomes an overwhelmingly personal crisis. Brill, as the protagonist, can remove the boring of his chronic insomnia by inventing a story about an America torn apart, and movie watching, here, Auster, actually, compare the war on terror to films, he wants to remind people of thinking human being's future in oblique way, not just to watch the war on terror as movie watching, escaping into war on terror, Americans should read it like a book with "intelligence and imagination", as Brick once said, whatever caused the war, and whatever issues or ideas happen to be at stake, none of it makes any sense. To some extent, the embedded story is an objective of the contrast with the frame story, in which Auster expresses his ideas on war on terror in oblique ways. There is a great contrast between the frame story and embedded fictional narrative, in August Brill's imagined, split America, rather than United States, because some states are disunited, the Trade Center is still standing, as there has never been a 9/11 terrorist attack. There is no war in Iraq. That is without the need for actual outside enemies, but the civil war has gone from bad to worse. Auster stresses the significance of peace, he expresses it by Brill, "war has entered this house...Peace on earth, good will toward men." (320)

Although there are differences between Brill as the character in one story and August Brill as the author in another, Paul Auster strengthens the subjects through the two stories that make up Man in the Dark, the character and the author both present readers with president George Bush as an incapable figure of head of government, failed, irresponsible, careless. His failure leads to the bloody civil wars that disintegrates and tear the country into parts, and the invasion into Iraq and its fatal consequence that influences the lives of Brill and his family directly. Especially, in the embedded story of Man in the Dark, America is broken into different hostile halves. On the one hand, Brill arranges the civil war in his created story; on the other hand, some of his characters plot to figure out and assassinate Brill, the man in the dark, whose identity they know, the characters convinced that it is the ultimate way to track him down and finish off him to cease the craziness of the civil war and the meaningless, unending murder that is carried out all around the former United States of America. Authoring the world they live in, he is held both technically and morally responsible for their hopeless situation. August Brill, then, is, in a way, a reincarnation of the President Bush of the frame story- an inappropriate figure, who has upmost domination over the lives of his people/characters, but out of incompetence and a desire for control of power, consolidating his role by starting bloody, senseless wars. Both Bush and Brill, as authority figures, are presented as intolerably incompetent of playing their part. Americans do not know G. Bush's ability as the characters who want to murder Brill do not know Brill. Such unsuited head figures should be delegitimized, and they should symbolically (or literally, as the story within a story suggests) be eliminated. As the conspirators, also characters of the embedded story say about Brill in the interest of justifying the planned assassination, "the war in one man's head, and if this man eliminated, the war stop" (MD 69). Brill himself, in the realist frame story, could easily apply these words to President Bush.

\section{CONCLUSION}

In various crises in the city, from the extent of damage, the consumption is kind of self-outlet, compared to consumption, the racial prejudice is more radical, even violent, while the crisis arrives the peak in terrorism. Auster's greatness lies not only in his insistent efforts to compose novels in innovative way but also in figuring out a new direction for urban writing in the post-modern social and cultural context. His concerns with the contemporary and future city have profound and realistic significance to the promotion of outlook of the contemporary intellectual field.

\section{REFERENCES}

[1] Baudrillard, Jean. The Consumer Society: Myths and Structures London: Sage, 1998, pp 25.

[2] Mackay, Hugh. Consumption and Everyday Life. London: Sage Publications, 1997, pp 26.

[3] Baudrillard, Jean. Simulations. trans. Paul Foss. Paul Patton and Philip Beitchman New York: Semiotext, Inc., 1983, pp 5.

[4] Baudrillard, Jean.The Consumer Society: Myths and Structures London: Sage, 1998, pp 125.

[5] Uçar, Pürnur. "The Formation of Identity in the Simulacrum: A PostModern Analysis of Paul Auster's Timbuktu." Irwle 4 (1) (2008), pp 7.

[6] Morris, Mary. "A Conversation with Paul Auster." Conversations with Paul Auster. ed. Hutchisson James M. Jackson: University Press of Mississippi,2013, pp 164

[7] Weber, Max. The Protestant Ethic and the Spirit of Capitalism. Trans. Talcott Parsons. London: Routledge, 2005.

[8] Althusser, Louis. "Ideology and Ideological State Apparatuses." Lenin and Philosophy and Other Essays. ed. Ben Brewster. New York: Monthly Review Press, 1971,pp 12.

[9] Woods, T. "The Music of Chance: Aleatorial (Dis)harmonies." Beyond the Red Notebook. ed. D. Barone. Philadelphia: University of Pennsylvania Press, 1995, pp 159

[10] Emerson, Ralph Waldo. "Politics." The Collected Works of Ralph Waldo Emerson. ed. Joseph Slater and Douglas Emory Wilson. London: Belknap Press, 1983, pp 122 
[11] Thoreau, Henry David. "Resistance to Civil Government." The Reform Papers. ed. Wendell Glick. Princeton: Princeton University Press, 1973, pp 76. 